\title{
Climate Change Effects on Temperate Grassland and Its Implication for Forage Production: A Case Study from Northern Germany
}

\author{
Iraj Emadodin ${ }^{1, *}$, Daniel Ernesto Flores Corral ${ }^{2}$, Thorsten Reinsch ${ }^{1} \mathbb{D}$, Christof Kluß ${ }^{1} \mathbb{D}$ and Friedhelm Taube ${ }^{1,3}$ \\ 1 Group Grass and Forage Science/Organic Agriculture, Institute for Crop Science and Plant Breeding, \\ Christian-Albrechts-University, 24118 Kiel, Germany; treinsch@gfo.uni-kiel.de (T.R.); \\ ckluss@gfo.uni-kiel.de (C.K.); ftaube@gfo.uni-kiel.de (F.T.) \\ 2 Global Center on Adaptation, 9747 AG Groningen, The Netherlands; florescorraldaniel@gmail.com \\ 3 Grass Based Dairy Systems, Animal Production Systems Group, Wageningen University (WUR), \\ 6708 PB Wageningen, The Netherlands \\ * Correspondence: iemadodin@gfo.uni-kiel.de
}

Citation: Emadodin, I.; Corral, D.E.F.; Reinsch, T.; Kluß, C.; Taube, F. Climate Change Effects on Temperate Grassland and Its Implication for Forage Production: A Case Study from Northern Germany. Agriculture 2021, 11, 232. https://doi.org/ 10.3390 /agriculture 11030232

Academic Editor: Ritaban Dutta

Received: 1 February 2021

Accepted: 6 March 2021

Published: 10 March 2021

Publisher's Note: MDPI stays neutral with regard to jurisdictional claims in published maps and institutional affiliations.

Copyright: (c) 2021 by the authors. Licensee MDPI, Basel, Switzerland. This article is an open access article distributed under the terms and conditions of the Creative Commons Attribution (CC BY) license (https:// creativecommons.org/licenses/by/ $4.0 /)$.

\begin{abstract}
The effects of climate change on agricultural ecosystems are increasing, and droughts affect many regions. Drought has substantial ecological, social, and economic consequences for the sustainability of agricultural land. Many regions of the northern hemisphere have not experienced a high frequency of meteorological droughts in the past. For understanding the implications of climate change on grassland, analysis of the long-term climate data provides key information relevant for improved grassland management strategies. Using weather data and grassland production data from a long-term permanent grassland site, our aims were (i) to detect the most important drought periods that affected the region and (ii) to assess whether climate changes and variability significantly affected forage production in the last decade. For this purpose, long-term daily weather data (1961-2019) and the standardized precipitation index (SPI), De Martonne index ( $\left.\mathrm{I}_{\mathrm{DM}}\right)$, water deficit (WD), dryness index (DI), yield anomaly index (YAI), and annual yield loss index (YL) were used to provide a scientific estimation. The results show that, despite a positive trend in DI and a negative trend in WD and precipitation, the time-series trends of precipitation, WD, and DI indices for 1961-2019 were not significant. Extreme dry conditions were also identified with SPI values less than -2 . The measured annual forage yield (2007-2018) harvested in a four-cut silage system (with and without organic $\mathrm{N}$-fertilization) showed a strong correlation with $\mathrm{WD}(R=0.64 ; p<0$. 05). The main yield losses were indicated for the years 2008 and 2018. The results of this study could provide a perspective for drought monitoring, as well as drought warning, in grassland in northwest Europe.
\end{abstract}

Keywords: grassland ecosystem; climatic variability; climate changes; drought monitoring; Germany

\section{Introduction}

Recent atmospheric warming and climate change have the potential for significant effects on agriculture systems and their productivity [1,2]. Crop and livestock-forage systems are particularly vulnerable to adverse changes in temperature and precipitation when they impact cultivation, sowing, growth, and utilization. Changes in precipitation and seasonal water regimes can result in increased drought, thereby greatly affecting productivity [3]. Anthropogenic climate change, attributed to the greatly increased greenhouse gas (GHG) emissions since the 19th century, has been identified as a cause of increased frequency and severity of droughts $[4,5]$. Drought is a major contributing factor to land degradation [6], a process that is further accelerated by unsustainable land-use practices such as overgrazing and urbanization [7-12], and it has serious potential consequences for global food security. A drought event is considered to occur when there is a significant decrease in water availability over a critical period compared with normal levels [13-15]. 
Thurow and Taylor [16] classify droughts as meteorological, agricultural, hydrological, and socioeconomic. A meteorological drought is considered to occur when there is a significant reduction in precipitation relative to the climatologically expected mean, which varies depending on the location [17]. Agricultural drought is considered to take place when soil moisture falls below the climatically appropriate moisture availability, thereby adversely affecting crop yield and increasing plant stress and mortality [18]. Different crops react differently to water stress. Furthermore, an agricultural drought depends on the land management, soil type, temperature, and access to technology, such as irrigation systems. A hydrological drought is defined as a condition in which water availability decreases with regard to both surface and groundwater levels [13]. For instance, several days without rainfall plus continuous use of surface river water for human purposes might reduce supplies for water storage, thereby affecting agricultural sectors both directly and indirectly. However, drought events are unavoidable due to the behaviour of hydrological processes and phenomena that create them $[19,20]$. While it is often assumed that droughts occur only in arid and semi-arid climates, they may also occur in other types of climate [21]. The identification and characterization of droughts are complex, because they are difficult to detect [22]. Therefore, the study of drought requires a multidisciplinary analysis [23] and requires as wide a characterization as possible, identifying duration, intensity, magnitude, and frequency [20].

In the case of Europe, future climate change under the Representative Concentration Pathway (RCP 4.5) scenario indicates that annual average land temperature is projected to rise by the end of this century by between $1.4{ }^{\circ} \mathrm{C}$ and $4.2^{\circ} \mathrm{C}[1,24]$. The European Environmental Agency has indicated that the frequency, duration, and severity of meteorological and hydrological droughts will increase throughout Europe [25]. Furthermore, while countries with arid and semi-arid climates might be relatively well prepared for drought, for instance, with irrigation systems in place, as drought is a more frequent and anticipated occurrence, countries with humid climates might be less well prepared, as drought is a less frequent natural event [25]. As a result of increasing temperature, evapotranspiration increases and plants become more vulnerable to periods with low rainfall [26,27]. Seedlings and newly established plants are especially susceptible to drought, and spring drought has the potential to impact grassland yields during early summer, especially of newly sown swards $[27,28]$.

According to Craine et al. [29], drought not only reduces plant productivity and increases plant mortality, but it also limits the geographic distribution of plant species and accelerates grassland degradation. Degradation is not only related to the effects of biotic factors (e.g., overgrazing by animals), but also to how abiotic (e.g., soil and water) factors regulate these systems. Therefore, grassland management requires a knowledge base of the effects and interactions of biotic and abiotic components, as well as socioeconomic factors (Figure 1).

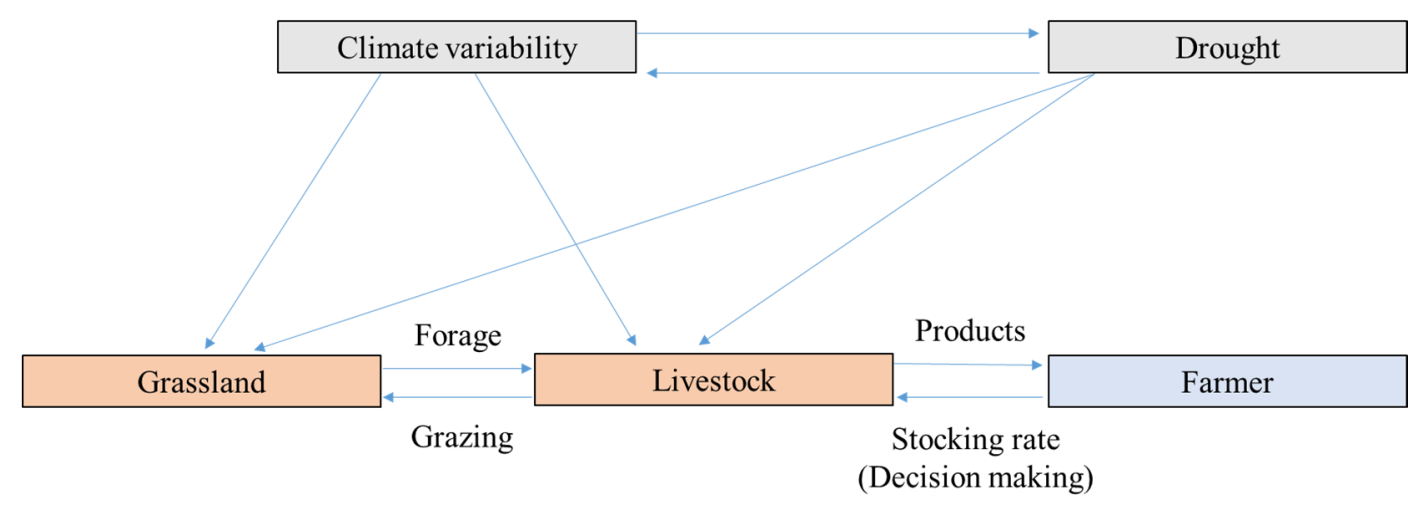

Figure 1. The relationships among climate variability, drought, and grassland ecosystems. 
Grasslands cover more than one-third of the European agricultural land; they have an important role in feeding domestic and wild animals, and they provide important ecosystem services [30]. Compared with many arable crops, grasslands are able to provide a buffer against climate variability, as they contain a diversity of plants that respond differently to extreme environmental phenomena [31]. However, it remains unclear how drought tolerance among different grassland plants changes along climate gradients [29]. Studies that assess the impacts of extreme weather events such as drought in humid grassland ecosystems are also lacking, and there is an increasing need to address this knowledge gap. For instance, in 2003, evidence indicated that grass production was reduced by around $30 \%$ in Europe due to heatwave and drought [32]. Recently, drought intensity and duration have increased, and both have had major impacts on the structure of grassland ecosystems [27]. In 2019, historically low pasture yields were observed in central Europe [33] with high economic losses for the ruminant industry. Moreover, droughts alter the microbial composition of the soil, potentially affecting microbial interaction with plants $[28,34]$. Drought could also affect the carbon cycle, accelerate plant mortality, increase the spread of plant diseases, decrease soil quality, and increase fire risks $[27,28,35]$. Lei et al. [28] further commented that the drought impact on carbon allocation is still unclear, but that elevated losses of soil organic carbon are adding to GHG emissions from grassland soils.

Therefore, there is a need for further research to enable a better assessment of the future impacts of drought on grassland ecosystems in Europe. To date, no study has assessed the effect of climatic and atmospheric drivers on grassland production in northern Germany with reference to grassland production data obtained in a field setting. Thus, we used the dataset from an existing long-term permanent grassland experiment (2007-2018) to investigate the potential likelihood of yield losses as a result of climate change in the area of Schleswig-Holstein, northern Germany. The main focus of the research reported here is to detect the most important drought episodes and to assess whether changes in climate significantly affected forage production in the last decade in this area of Germany.

\section{Materials and Methods}

\subsection{Study Area}

The investigation site was located in Schleswig-Holstein $\left(54^{\circ} 28^{\prime} 12^{\prime \prime}\right.$ north $(\mathrm{N}), 9^{\circ} 30^{\prime} 50^{\prime \prime}$ east (E)), Germany (Figure 2). The weather data used in this study were obtained from a synoptic weather station located at Kiel-Holtenau $\left(54^{\circ} 22^{\prime} 39^{\prime \prime}\right.$ N, $10^{\circ} 08^{\prime} 32.6^{\prime \prime}$ E, elevation $28 \mathrm{~m}$ above sea level (a.s.l.)) for the period from 1961 to 2019. This was the nearest weather station to the study site. The average annual precipitation is $773 \mathrm{~mm}$ and the annual temperatures average $8.9^{\circ} \mathrm{C}$. In July and August, the warmest months of the year, the mean air temperature is around $16.9^{\circ} \mathrm{C}$. (Figure 3). Field sampling was carried out at the Kiel University farm "Lindhof" close to the Baltic Sea $\left(54^{\circ} 27^{\prime}\right.$ N, $9^{\circ} 57^{\prime}$ E, elevation $10 \mathrm{~m}$ a.s.l.) [36]. The soil was sandy loam, classified as a Eutric Luvisol, with a texture composition of $11 \%$ clay, $29 \%$ silt, and $60 \%$ sand in the top $30 \mathrm{~cm}$ of soil [37].

\subsection{Drought and Aridity Indices}

Drought indices are indispensable tools for drought analysis and monitoring since they allow both the identification and the quantification of droughts [38]. There are several drought indices such as the rainfall variability index (RVI), standardized precipitation index (SPI), Palmer hydrological drought index (PHDI), standardized precipitation evapotranspiration index (SPEI), surface water supply index (SWSI), Palmer drought severity index (PDSI), and standardized anomaly index (SAI) [39-42]. In this study, the SPI was applied, because of its good characteristics in drought identification and the prediction of drought class transitions $[41,43,44]$. The SPI was used widely during the first decade of the 21st century as a statistical indicator, as it is simple and considers only precipitation data $[38,45]$. This index was first suggested by McKee et al. in 1993 [46] and is also recommended by the World Meteorological Organization (WMO) [47] for indicating and monitoring drought 
for different predefined timescales ( 1 month, 3 months, 6 months, 12 months, etc.). The timescale refers to the number of months to be aggregated in the calculation of the SPI, with different timescales reflecting the influences of precipitation shortage on different water resources. For example, soil moisture and groundwater respond to precipitation anomalies over a relatively short scale and long scale, respectively.

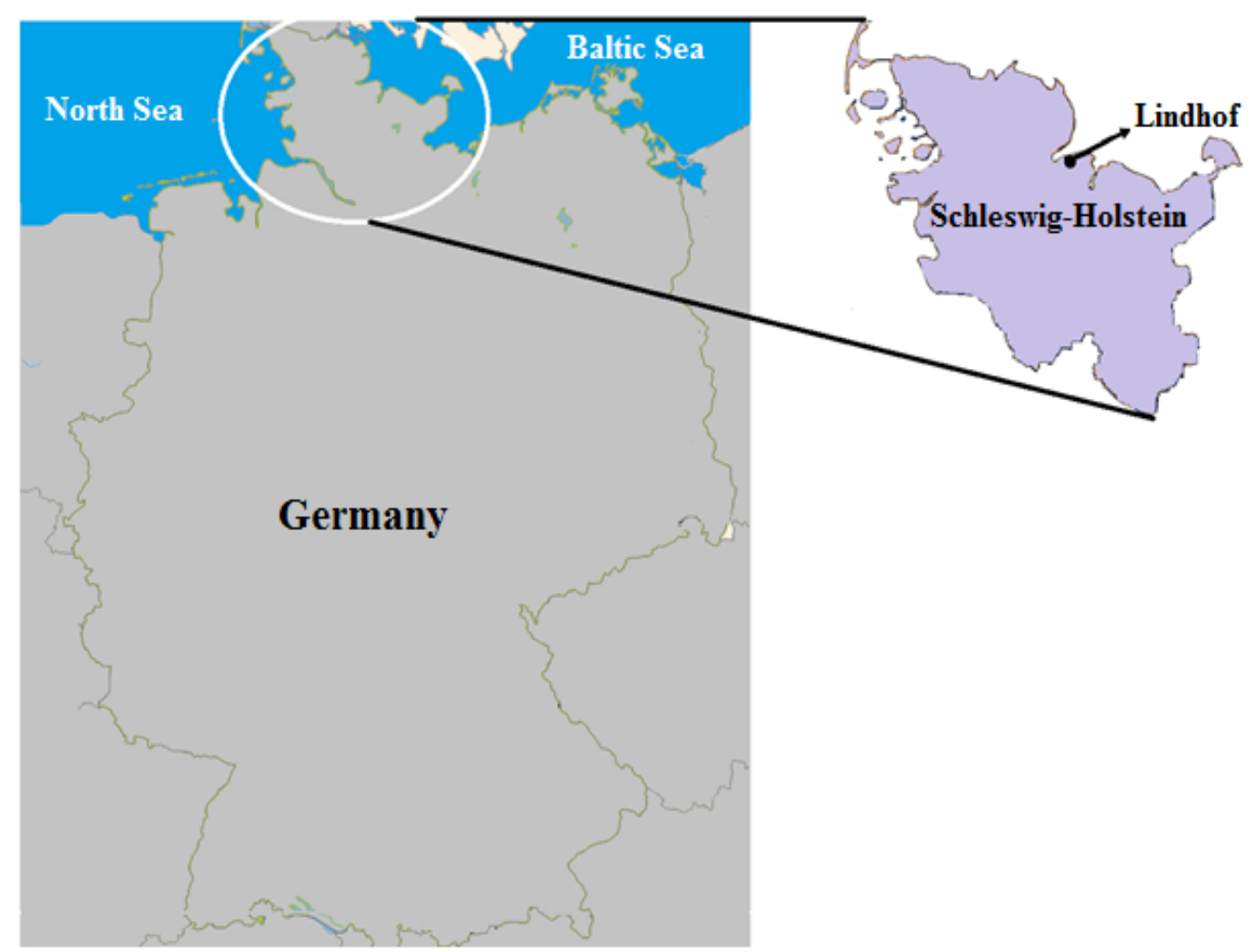

Figure 2. Location of the study area.

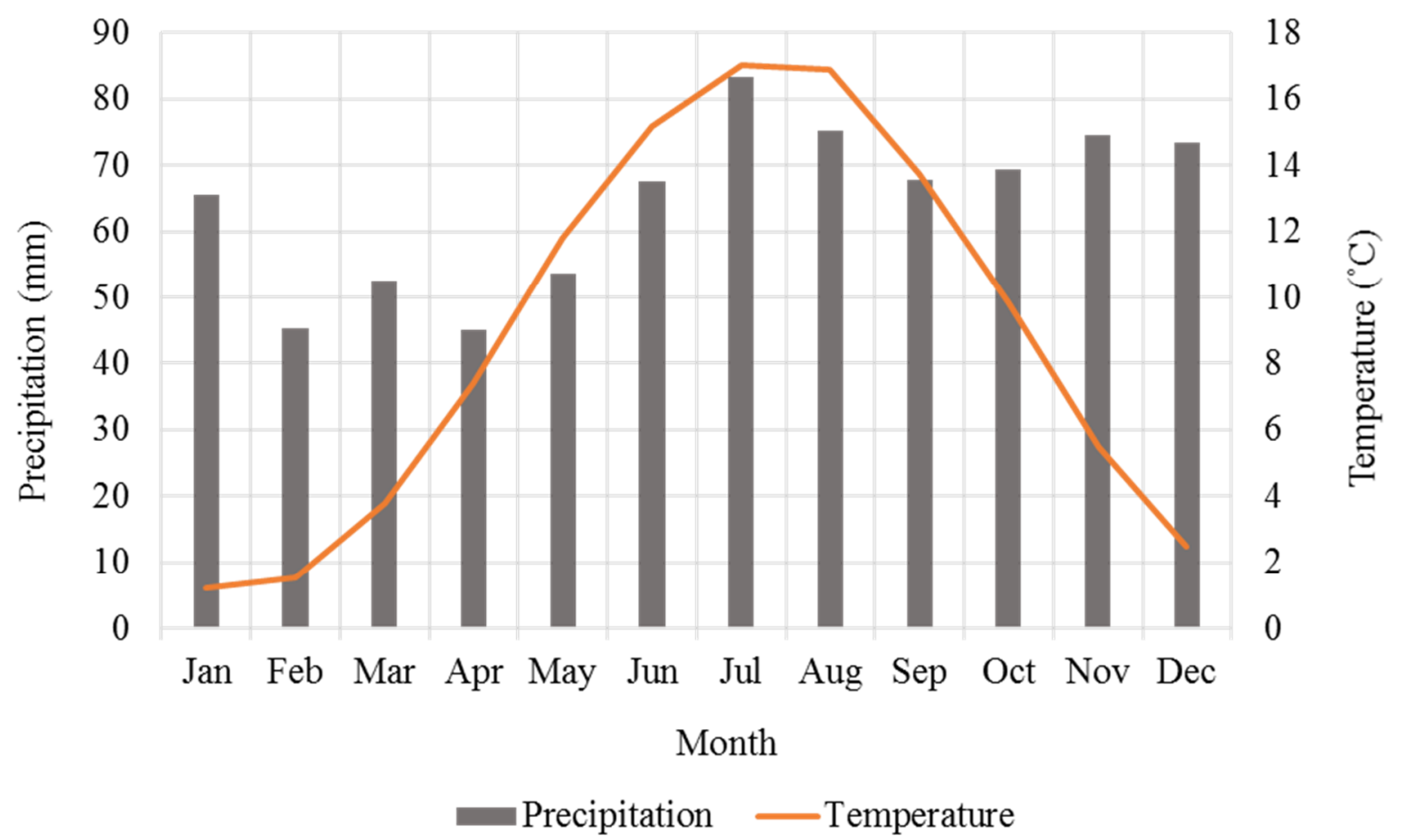

Figure 3. Average monthly precipitation and temperature in the study area (1961-2019). 
It is widely recommended that drought should be estimated from a regional perspective, because results from different case studies are not necessarily comparable with those from other regions [48,49]. In regional studies, drought indices should be standardized [50] accordingly, and the SPI index has this characteristic. SPI represents precipitation values using a gamma distribution (Equation (1)). This distribution is sometimes used to determine the appropriate model according to the dataset [51,52]. The SPI is the most used drought indicator worldwide because of its applicability in all climate regimes [49]. Table 1 shows the classification of SPI values. Values in the range -0.50 to -0.99 are also considered as indicators of mild drought [53].

$$
g(x)=\frac{x^{a-1} \cdot e^{x / s s}}{s s^{a} \cdot r(a)} \text { forx }>0
$$

Table 1. Classification of wet and dry periods based on standardized precipitation index (SPI).

\begin{tabular}{ccc}
\hline Category & SPI Value & Probabilities (\%) \\
\hline Extremely wet & $\geq 2$ & 2.3 \\
Very wet & 1.5 to 1.99 & 4.4 \\
Moderately wet & 1.0 to 1.49 & 9.2 \\
Near normal & -0.99 to 0.99 & 68.2 \\
Moderately dry & -1.0 to -1.49 & 9.2 \\
Severely dry & -1.5 to -1.99 & 4.4 \\
Extremely dry & $\leq-2$ & 2.3 \\
\hline
\end{tabular}

The WMO [50] lists the following advantages of the SPI index:

- It is flexible and it can be calculated for various time scales.

- It has spatial coherence, because it allows comparisons between locations with different climates.

- For short time scales, this index provides early alerts of drought and helps to assess severity.

- The probabilistic origin of the SPI index shows a historical context. This is suitable for decision-making [20].

Table 1 shows a classification of SPI values into seven different precipitation regimes from wet to dry, with a standardized normal distribution for each SPI value. By this classification, the onset of drought occurs when the SPI value reaches -1.0 and ends when it returns to a positive value $[46,47]$.

Since the SPI considers only precipitation as the input data, there is also a need to consider related indices that show temperature and evapotranspiration effects. Therefore, the De Martonne aridity index $\left(\mathrm{I}_{\mathrm{DM}}\right)$, the difference between precipitation and evapotranspiration (water deficit index (WD)), and the ratio between precipitation and evapotranspiration (dryness index (DI)) were also calculated. The $\mathrm{I}_{\mathrm{DM}}$ index is one of the best known and widely used aridity indices [54]. The WD index provides a simple measure of the water surplus or deficit for different time scales, and it represents climate water balance for the study area [55]. The $\mathrm{I}_{\mathrm{DM}}$ decreases with increasing aridity and is calculated using the following equation [56] (Table 2):

$$
\mathrm{I}_{\mathrm{DM}}=\mathrm{P} /(\mathrm{T}+10),
$$

where $\mathrm{P}$ is the annual precipitation $(\mathrm{mm})$, and $\mathrm{T}$ is the annual mean air temperature $\left({ }^{\circ} \mathrm{C}\right)$. 
Table 2. Type of climate according to the de Martonne aridity index $\left(\mathrm{I}_{\mathrm{DM}}\right)$.

\begin{tabular}{cc}
\hline Climate Type & I $_{\mathrm{DM}}$ Values \\
\hline Arid & $\mathrm{I}_{\mathrm{DM}}<10$ \\
Semi-arid & $10 \leq \mathrm{I}_{\mathrm{DM}}<20$ \\
Mediterranean & $20 \leq \mathrm{I}_{\mathrm{DM}}<24$ \\
Semi-humid & $24 \leq \mathrm{I}_{\mathrm{DM}}<28$ \\
Humid & $28 \leq \mathrm{I}_{\mathrm{DM}}<35$ \\
Very humid & $35 \leq \mathrm{I}_{\mathrm{DM}}<55$ \\
Extremely humid & $\mathrm{I}_{\mathrm{DM}}>55$ \\
\hline
\end{tabular}

The following formula was used for calculation of the WD index:

$$
\mathrm{WDi}=\mathrm{P}_{\mathrm{i}}-\mathrm{PET}_{\mathrm{i}}
$$

where $\mathrm{PET}_{\mathrm{i}}$ is the annual evapotranspiration $(\mathrm{mm})$, and $\mathrm{P}_{\mathrm{i}}$ is the annual precipitation $(\mathrm{mm})$ and

The following formula was used for calculation of DI:

$$
\mathrm{DI}_{\mathrm{i}}=\mathrm{PET}_{\mathrm{i}} / \mathrm{P}_{\mathrm{i}} \text {. }
$$

On the basis of $\mathrm{DI}_{\mathrm{i}}$ values, climatic regimes can be classified into four groups: arid $\left(12>\mathrm{DI}_{\mathrm{i}} \geq 5\right)$, semiarid (5>DI $\left.\geq 2\right)$, subhumid $\left(2>\mathrm{DI}_{\mathrm{i}} \geq 0.75\right)$, and humid (0.75 $\left.>\mathrm{DI}_{\mathrm{i}} \geq 0.37\right)$ [57]

\subsection{Experimental Design and Field Sampling}

The experimental field was used as arable land within a 5 year crop rotation until 1993. In 1994, a grass-clover ley was undersown in a cereal crop, and it has been managed as long-term permanent grassland since then. From 1994 to 2004, the grassland was managed in a mixed cutting and grazing system (two silage cuts and two to three grazing cycles with suckler cows per year). In 2005, a randomized field experiment with three replicates for different experimental purposes [37,58,59] was established.

The permanent grassland experiment used in this study comprised a two-factorial design with three replicates of each treatment. The plot size of each replicate was $6 \mathrm{~m} \times 12 \mathrm{~m}$ $(n=3)$.

The factor $\mathrm{N}$-fertilization was carried out using cattle slurry in amounts that supplied a total of $240 \mathrm{~kg} \mathrm{~N} \cdot \mathrm{ha}^{-1} \cdot$ year $^{-1}$, compared with a non-N-fertilized control. The slurry was applied with trailing hoses on four occasions each year, with one application for each

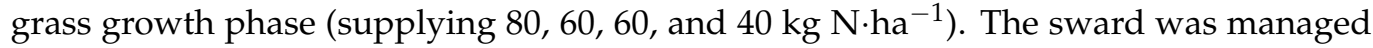
by taking four cuts per year, each harvested at a "silage" growth stage. All plots received $45 \mathrm{~kg} \mathrm{P} \cdot \mathrm{ha}^{-1}, 100 \mathrm{~kg} \mathrm{~K} 2 \mathrm{O} \cdot \mathrm{ha}^{-1}, 24 \mathrm{~kg} \mathrm{Mg} \cdot \mathrm{ha}^{-1}$, and $68 \mathrm{~kg} \mathrm{~S} \cdot \mathrm{ha}^{-1}$ every 2 years. The years 2007-2018 comprised the factor experimental year.

Each plot was harvested with a Haldrup forage harvester (Haldrup, Løgstør, Denmark) at a cutting height of $5 \mathrm{~cm}$. The total fresh matter (FM) weight of each plot was recorded immediately after harvesting. Subsamples ( 150 g of FM) were taken and ovendried to constant weight at $58^{\circ} \mathrm{C}$ to determine their dry matter (DM) content, thereby allowing calculation of DM yield. The sward composition was estimated according to Klapp and Stählin [60] after the third silage cut on each plot in irregular annual intervals (every 2-3 years). On average, the dominant species in the non-N-fertilized treatment was perennial ryegrass (Lolium perenne) at 49\%. The balance consisted of 5\% Phleum pratense, $12 \%$ Poa trivialis, 6\% Dactylis glomerate, 13\% Trifolium repens, $8 \%$ Taraxacum sect. Ruderalia, and $7 \%$ various other species. In the slurry N-fertilized treatment, Lolium perenne contributed $60 \%$, with $4 \%$ Phleum pratense, 11\% Poa trivialis, 1\% Dactylis glomerate, 4\% Trifolium repens, 9\% Taraxacum sect. Ruderalia, and 11\% from various other species. All plots were oversown every 3 years with Lolium perenne at a seeding rate of $10 \mathrm{~kg} \cdot \mathrm{ha}^{-1}$. 


\subsection{Yield Anomaly Index (YAI)}

The yield anomaly index helps to recognize the deviation of yield for a particular year from the long-term trend. YAI is calculated using the following formula:

$$
\mathrm{YAI}_{\mathrm{i}}=\left(\mathrm{Y}_{\mathrm{i}}-\mu\right) / \sigma,
$$

where $\mathrm{YAI}_{\mathrm{i}}$ represents the yield anomaly index for a selected year, $\mathrm{Y}_{\mathrm{i}}$ is the annual yield for the selected year, $\mu$ is the mean annual yield selected for a period of time, and $\sigma$ represents the standard deviation.

Annual Yield Loss (YL)

In order to estimate the annual yield loss $(Y L)$ under drought impact, two parameters are used, namely, annual yield $(Y)$ and potential yield $(Y P)$. In this study, potential yield (without water stress) was defined as the average of long-term yield that was not affected by water deficits (WD). The following equation was used to calculate $Y L$ :

$$
Y L i=\frac{(Y i-Y P i)}{Y P i} \times 100
$$

\subsection{Statistical Methods}

Linear regression analyses were performed for the entire period (1961-2019) to detect time-series trends. The moving average was used to smooth out fluctuations in the data and to detect patterns or trends more clearly. The R Package for SPI (version 2.3.0) was used to show the long-term frequency of drought in the study area.

\section{Results}

The temperature time series is shown in Figure 4. The time-series analysis indicated that the mean annual temperature of the study area increased continuously during the period 1961 to 2019. The slope of the regression line showed a significant increase in annual mean temperature (Figure 4). Time-series analysis for precipitation was also carried out. The slope of the regression line showed a small negative trend although this was not significant (Figure 4).

Figure 5 shows dry years with different dryness intensity, due to the low values of SPI (red area). Results show that, during the observation period (1961-2019), several severe or extremely dry episodes affected the study area, particularly over short time scales (1 and 3 month SPI). According to the classification of wet and dry periods (based on SPI index; Table 1), extreme dry conditions were identified for the investigation period (1961-2019) with SPI values of less than -2 for the different scales of SPI. Periods classified as severely dry and moderately dry could be seen in some years, with SPI values between -1.0 and -1.99 (Figure 5).

The trend of De Martonne aridity index ( $\mathrm{I}_{\mathrm{DM}}$ ) values in the analyzed period (19612019) was not significant but it represented a clear fluctuation (Figure 6). A maximum value of $\mathrm{I}_{\mathrm{DM}}$ occurred in $1980\left(\mathrm{I}_{\mathrm{DM}}=53.9\right)$ and a minimum value occurred in 2018 $\left(I_{D M}=26.1\right)$. The average of $I_{D M}$ for the estimated period was around 40 , which indicates a very humid climate type for the study area (Table 1). 

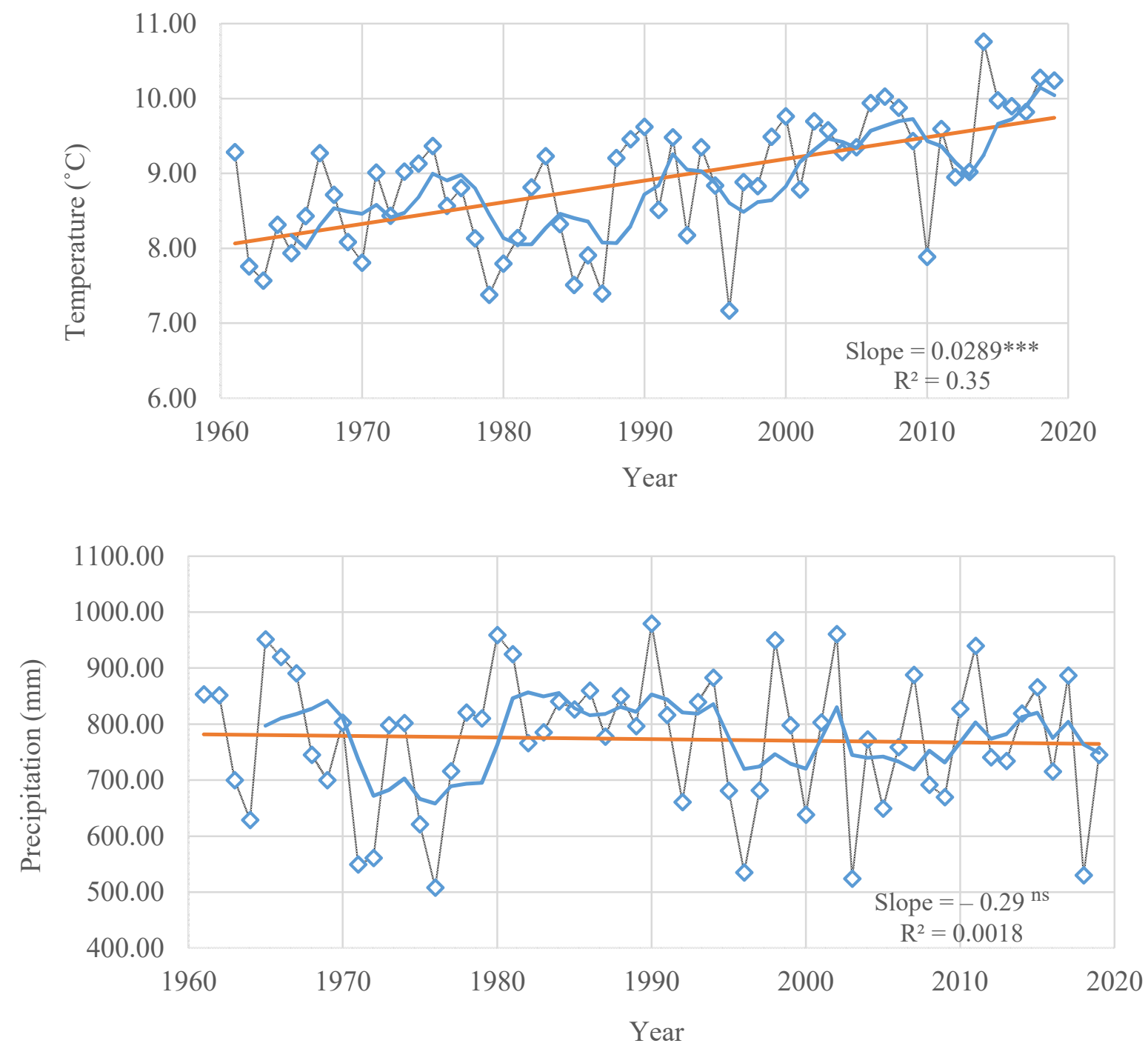

Figure 4. Time series of annual mean daily temperature and precipitation for the selected synoptic station (Kiel-Holtenau, 1961-2019). The solid red line shows a regression analysis, and the blue line denotes the 5 year moving average. Linear regression analyses test shows a significant trend $(* * *<0.001)$ in annual temperature. ns $=$ not significant.

The trend of WD and DI indices in the analyzed period (1961-2019) was not significant (Figure 7). Annual mean WD (the difference between precipitation and evapotranspiration) was around $296 \mathrm{~mm}$, with the positive value denoting that there was a precipitation surplus. According to the WD value (Figure 7), extreme water deficit occurred in 1976, 2003, and 2018 , with values below zero. The DI index also indicated a significant change in the climate regime in those years from humid $(0.75>\mathrm{DIi} \geq 0.37)$ to subhumid $(2>\mathrm{DIi} \geq 0.75)$. 

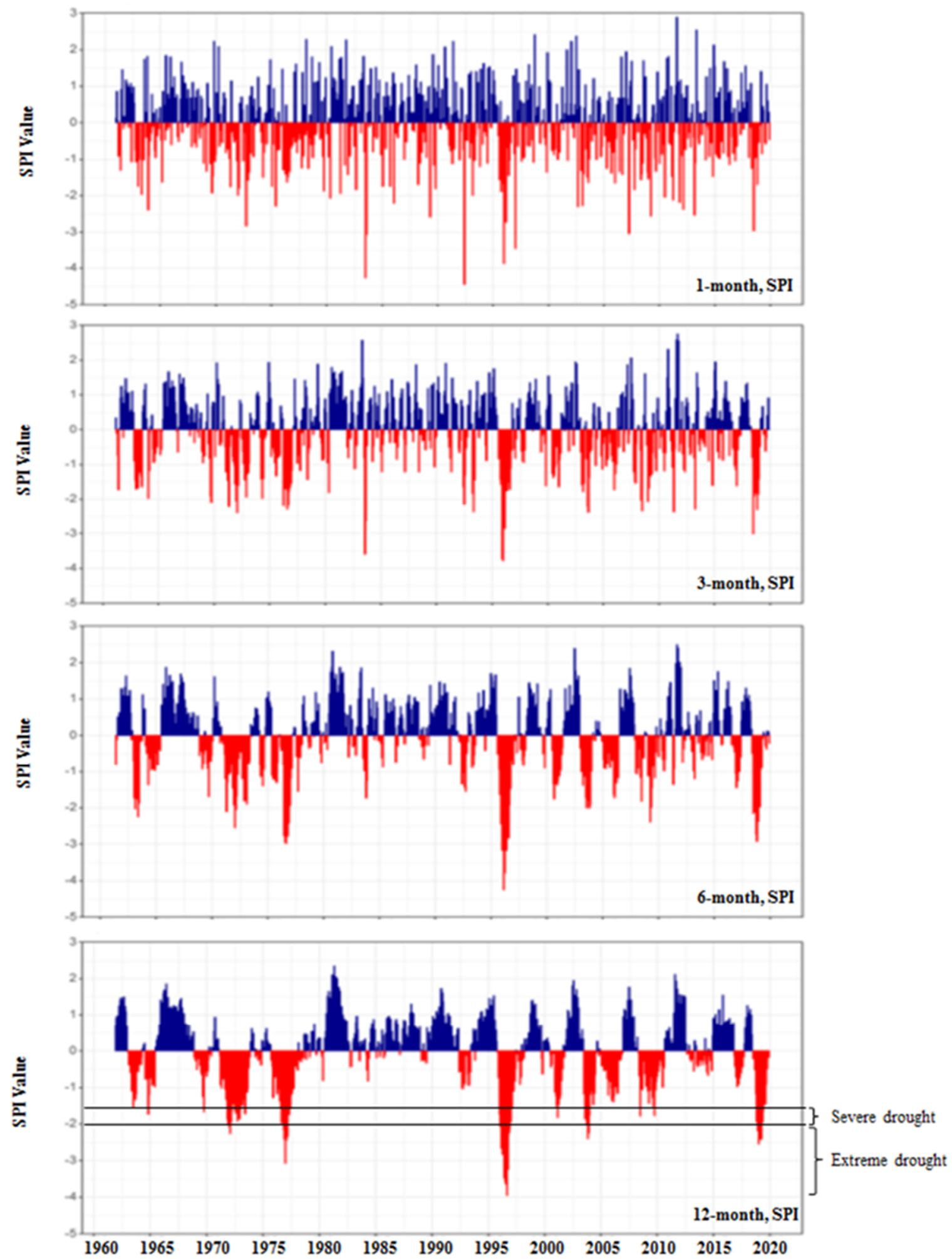

Figure 5. Time series of SPI-1, SPI-3, SPI-6, and SPI-12 at the Kiel-Holtenau synoptic station. 


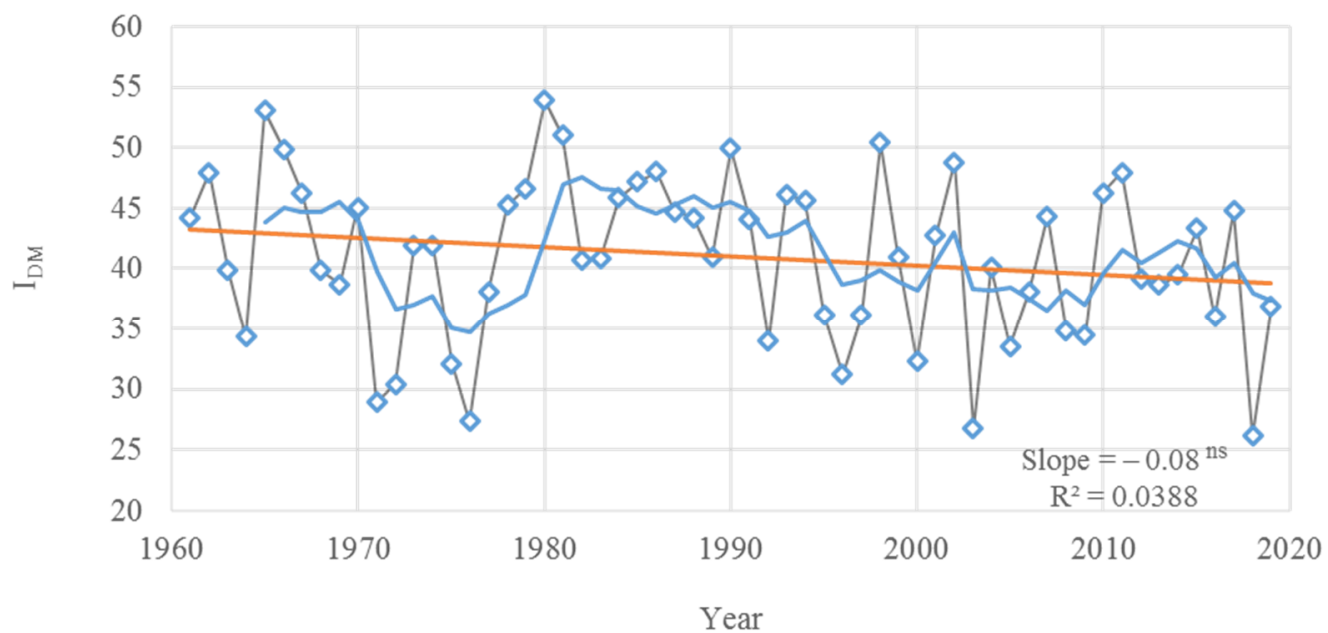

Figure 6. Time series of $I_{D M}$ for the selected synoptic station (Kiel-Holtenau). The blue line shows the 5 year moving average. The red line denotes a regression analysis. ns-not significant.
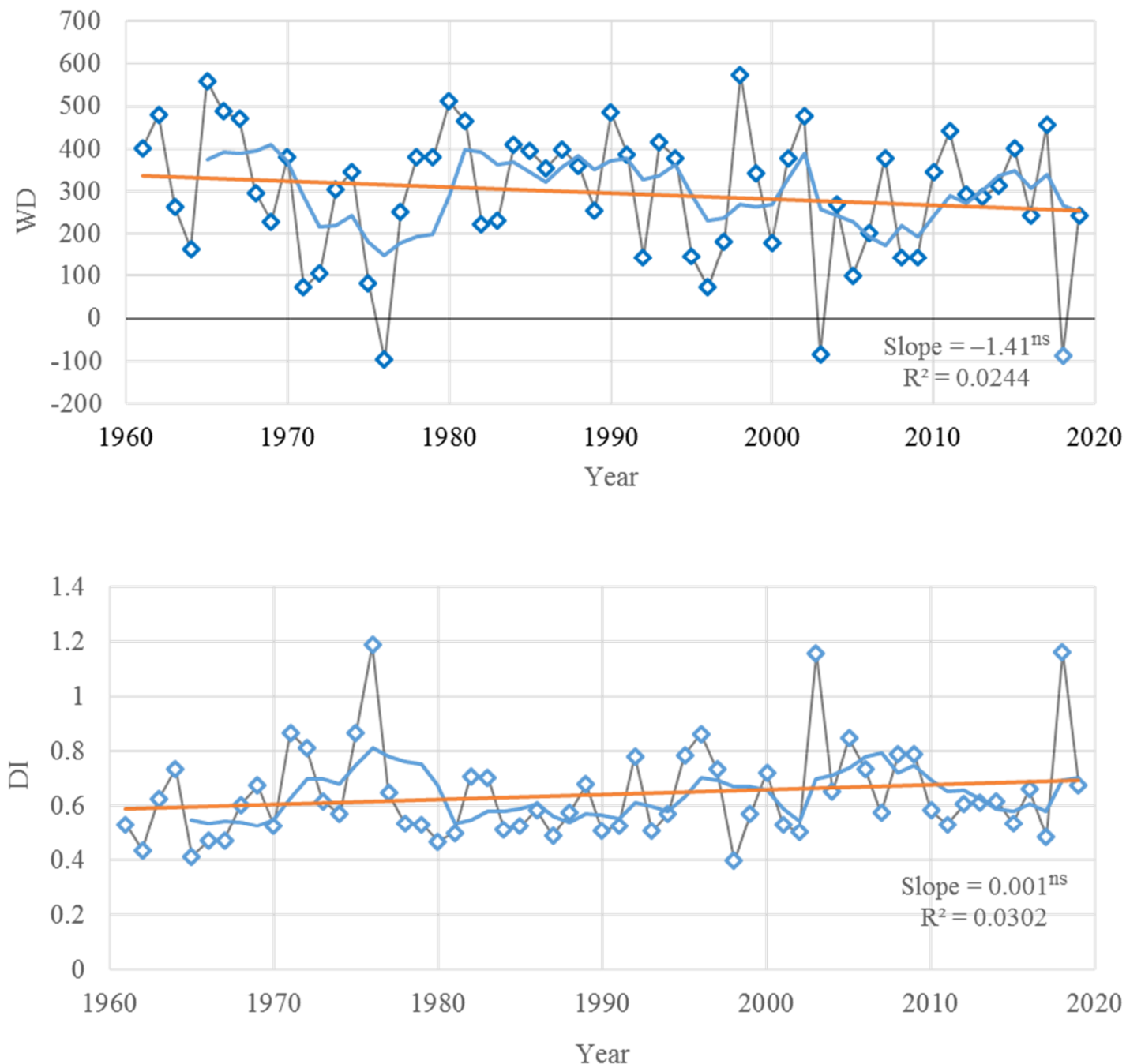

Figure 7. Time series of water deficit (WD) and dryness index (DI) for the selected synoptic station (Kiel-Holtenau). The blue line shows the 5 year moving average. The red lines denote a regression analysis. ns = not significant. 
The time-series analysis of grassland herbage yield under the two different fertilizer managements (with and without N-fertilizer) and WD for the selected period (2007-2019) showed negative trends (Figure 8a). The trend of the WD time series followed an annual fluctuation similar to that of the herbage yield, although no significant trend was shown (Figure 8a). The relationship between herbage yield and WD is shown in Figure 8b. A significant relationship $(R=0.64 ; p<0.05)$ was found between WD and herbage yield with regard to the fertilizer management.

(a)

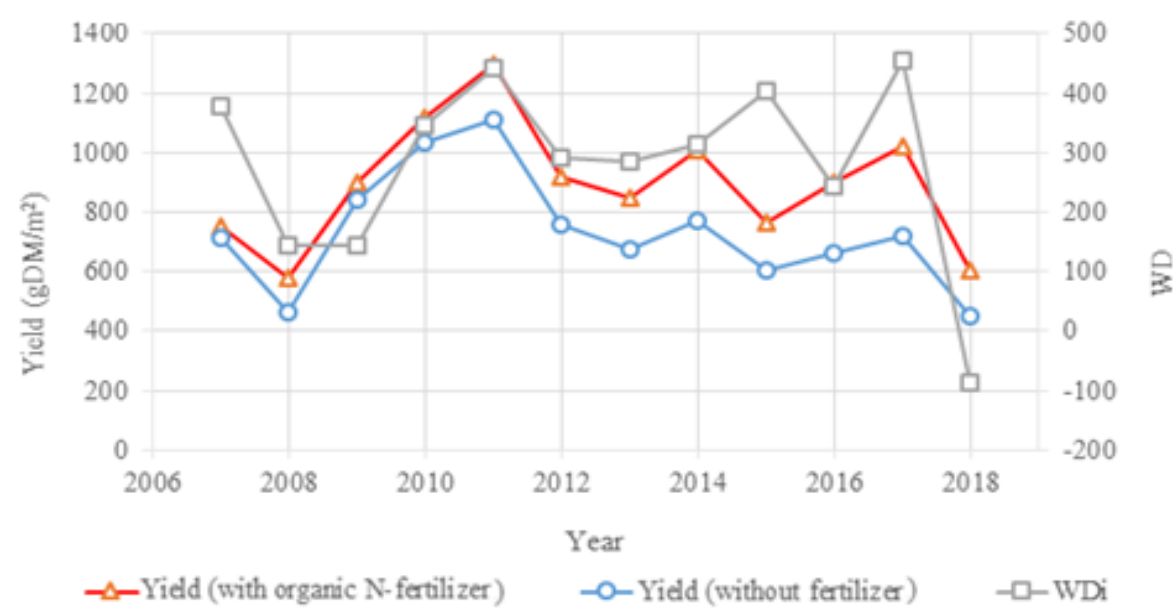

(b)

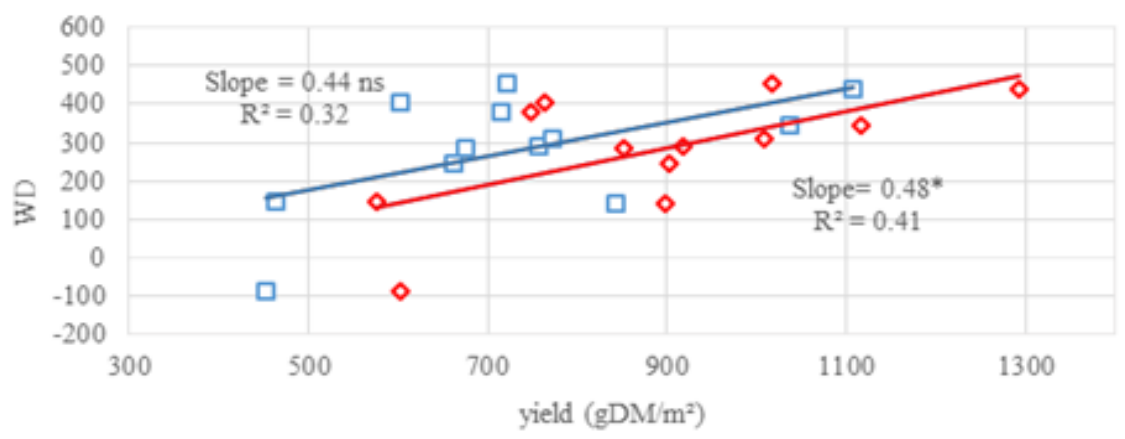

With organic N-fertilizer awithout fertilizer

Figure 8. (a) Time series of herbage yield and WD for the selected time period (2007-2018). (b) Dry matter (DM) yield values plotted against WD index. The lines denote a regression analysis. A significant relationship $\left({ }^{*} p<0.05\right)$ is shown between WD and herbage yield with regard to the fertilizer management. $\mathrm{ns}=$ not significant.

Figure 9 shows annual herbage yield loss during the investigation period (2007-2018). A high yield loss occurred in the years 2008 and 2018. There was no significant difference detected in loss of herbage yield under the two different fertilizer managements (with and without fertilizer) in the selected periods. The result for ID index reflected the relationship between annual yield lost and dryness in the study area (Figure 10), confirming that the time series of YAI and DI index showed the same trends and fluctuations. A sharp increase in the DI from 2007 to 2009 indicated yield loss, which was also repeated in 2017-2018. 


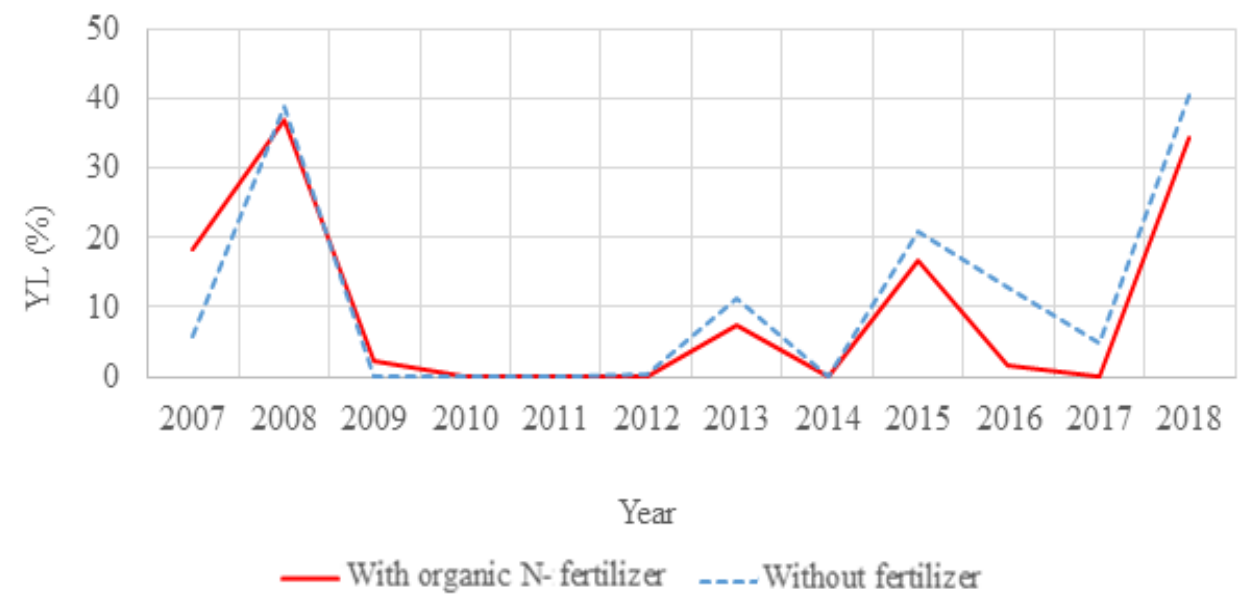

Figure 9. Annual herbage yield loss (as \%) in the study area under the two different fertilizer managements (2007-2018).

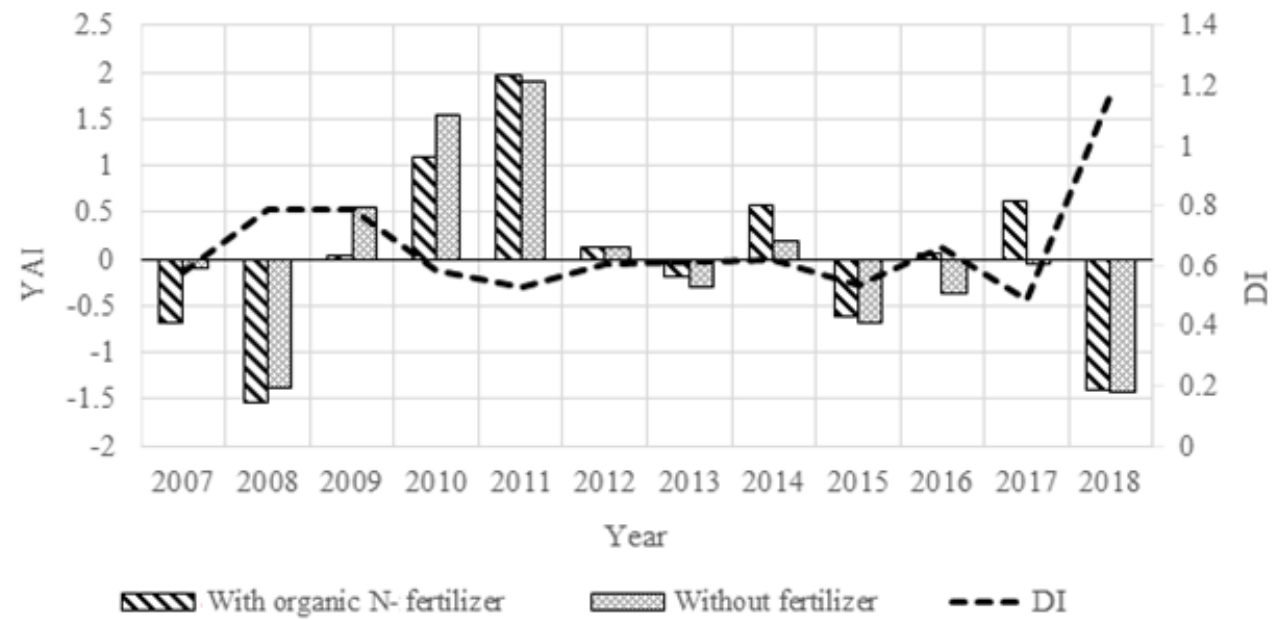

Figure 10. Time series of yield anomaly index (YAI) and DI for a selected time period (2007-2018).

\section{Discussion}

Analysis of the SPI for different predefined timescales showed large annual fluctuation in the occurrence of wet and dry events during the past few decades in the study area. Although severe droughts with SPI values lower than -2 were recorded in almost all decades between 1961 and 2019, three of the five most severe events occurred in the period 1990-2019.

Different drought intensities caused reductions in herbage yield that vary according to their severity (Table 3). Weather data for the study area indicate that, during the last few decades, the mean annual temperature has increased, with a significant trend, and that an increased frequency of meteorological droughts has also occurred. Increased air temperatures may also lead to increased soil temperature, as reported by Ooi et al. [61], who found that a rise of $1^{\circ} \mathrm{C}$ in daily maximum air temperature resulted in a soil temperature increase of around $1.5^{\circ} \mathrm{C}$, especially during dry conditions. These authors also stressed that rising soil temperature may impact future plant population dynamics. Climate change could also affect livestock production indirectly through its effects on forage quality and quantity, or directly by increasing temperatures [62], although, in some cases, seasonal changes may be advantageous, especially at times when soil water is not a limiting factor [1].

According to Foster et al. [63], a direct method for assessing drought influences in agriculture is to estimate productivity, as increases or decreases in productivity are mainly controlled by climate elements [64]. In the present study, yields of grass harvested for silage varied from 4-13 t DM.ha ${ }^{-1}$ between the years 2007 and 2018 and were mainly 
affected by fertilization and weather conditions. The application of cattle slurry (supplying $240 \mathrm{~kg} \mathrm{~N} \cdot \mathrm{ha}^{-1}$.year ${ }^{-1}$ ) increased the grassland productivity on average by $20 \%$. Comparable high silage yields, even in the non- $\mathrm{N}$-fertilized treatment, were mainly a result of the higher share of white clover in the unfertilized sward and its associated biological nitrogen fixation, which can account for as much as $193 \mathrm{~kg} \mathrm{~N} \cdot \mathrm{ha}^{-1} \cdot$ year $^{-1}$ in permanent grassland [36]. However, in terms of drought resistance, due to the vegetative reproduction system of white clover by branching stolons and the fine roots of the daughter plants, it can show considerable yield depressions particularly in spring-time droughts [36]. Despite this, the non-N-fertilized swards contained a higher share of Dactylis glomerata, which is generally relatively more tolerant of longer drought periods than Lolium perenne [36]. A high share of Lolium perenne in the sward is more likely at higher rates of $\mathrm{N}$-fertilization. In this context, Loges et al. [59] found a higher fraction of belowground biomass $(0-30 \mathrm{~cm}$ soil depth) derived from Lolium perenne after $\mathrm{N}$-fertilization. However, this might increase the probability of greater yield losses due to the higher vulnerability of Lolium perenne to reduced water availability. Thus, the two different fertilization regimes can lead to the development of different root function traits in the swards. This might explain the higher variation in yield in the non- $\mathrm{N}$-fertilized swards, leading to a nonsignificant correlation with WD even though the slope of the conducted regression analysis was almost the same as that of the slurry-N-fertilized treatment.

The results of the YAI analysis and its relationship with aridity indices confirmed the impacts of climate variability on grassland production in the study area. Results of the SPI in different time scales showed that the study area experienced some periods characterized by mild or moderate dryness, which might, therefore, have had possible effects via reduced soil moisture (Tables 3 and 4 ) during the last few decades. The results also indicated that the SPI index in the different time scales represented different types of drought severity (Table 4).

Between-year differences in herbage yield production and WD index values showed a similar trend and fluctuations (Figure 8a). This suggests that the WD index could provide decision-makers and insurers with a means for estimation and prediction of the impacts of drought on grassland production. As droughts are complex climatic phenomena and present a major threat to grassland ecosystem function, applying relevant and integrative indices is more appropriate than simply analyzing individual climatic factors. Balances among different plant species, as well as forage quality and abiotic factors in grassland, can be affected by climate change and between-year variability. Therefore, more detailed case studies are needed to enable monitoring of the impacts of climate change, especially drought severities, on grassland under different climatic zones.

Soil water also plays an important role in plant productivity and drought stress. It strongly affects grassland ecosystems [65] and net photosynthesis [66]. This investigation confirmed that, for a permanent grassland site in a temperate humid area of northwest (NW) Europe, a region where grassland contributes greatly to the livestock farming industry, there are periodic occurrences of water deficit stress that directly affect herbage production. According to Durand et al. [67], the nitrogen nutrition of crops will change under water deficits; in grasslands, water deficits adversely affect plant growth and nitrogen uptake. 
Table 3. Possible effects of dryness intensity (extracted and adapted from the National Drought Mitigation Center (NDMC) [68]).

\begin{tabular}{lll}
\hline Mildly dry & - & Slowing of plant growth \\
& - & Farmers respond by additional feed to livestock \\
\hline Moderately dry & - & $\begin{array}{l}\text { Some damage to pastures (e.g., yield reduction) } \\
\text { Water scarcity appears and develops }\end{array}$ \\
\hline Severely dry & - & Major herbage yield losses \\
& - & Widespread water shortage and limitation \\
\hline Extremely dry & - & $\begin{array}{l}\text { Intensive and extensive yield losses } \\
\text { Significant water scarcity in streams, wells, and reservoirs }\end{array}$ \\
\hline $\begin{array}{ll}\text { Table 4. Different SPI indicators for estimating potential impacts of a drought (extracted and adapted } \\
\text { from the European Drought Observatory (EDO) [69]). }\end{array}$ \\
\hline SPI-1 to SPI-3 & Considered as indicators for short-term impacts such as reduced soil moisture \\
\hline SPI-3 to SPI-12 & Considered as indicators for reduced stream flow and reservoir storage \\
\hline
\end{tabular}

\section{Conclusions}

This study examined the effects of recent climate change in relation to annual differences in production on a permanent grassland site in Schleswig-Holstein (northern Germany), using a time-series analysis of precipitation and temperature, as well as SPI, $\mathrm{I}_{\mathrm{DM}}, \mathrm{WD}, \mathrm{DI}, \mathrm{YAI}$, and YL indices. Temperature showed a significant increasing trend. The time-series trends for precipitation, i.e., WD and DI indices, in the analyzed period (1961-2019) were not significant but showed a positive trend in DI and a negative trend in WD values. Results also indicated that, in the observation period, there were several severe or extreme dry episodes that affected the study area, particularly over a short time scale (1 and 3 month SPI). There was an annual yield loss detected from 2007 to 2009. The main yield loss occurred in the years 2008 and 2018 (around 35-40\%).

A positive relationship between the DI index and YAI was found. As droughts are complex climatic phenomena, the use of relevant and integrative indices has advantages compared with a simple analysis of individual climatic factors. As droughts present a threat to grassland ecosystem functioning and grassland production, more case studies are needed to enable monitoring of the impacts of climate change, especially drought severities, on grassland under different climatic zones.

Author Contributions: Conceptualization, I.E.; methodology, I.E., D.E.F.C. and T.R.; formal analysis, I.E., D.E.F.C. and C.K.; investigation, I.E., D.E.F.C. and T.R.; data curation and analysis, I.E., D.E.F.C. and C.K.; writing—original draft preparation, I.E.; reviewing and editing, T.R., D.E.F.C., C.K. and F.T.; funding acquisition, F.T. All authors have read and agreed to the published version of the manuscript.

Funding: This research received no external funding.

Institutional Review Board Statement: Not applicable.

Informed Consent Statement: Not applicable.

Data Availability Statement: The data presented in this study are available on request from the corresponding author. 
Acknowledgments: The authors gratefully thank the two anonymous reviewers for their constructive suggestions and comments. We also acknowledge financial support by DFG within the funding program Open Access Publishing.

Conflicts of Interest: The authors declare no conflict of interest.

\section{References}

1. Hopkins, A.; del Prado, A. Implications of climate change for grassland management: Impacts, adaptations and mitigation options: A review. Grass Forage Sci. 2007, 62, 118-126. [CrossRef]

2. Anwar, M.R.; Li Liu, D.; Macadam, I.; Kelly, G. Adapting agriculture to climate change: A review. Theor. Appl. Climatol. 2013, 113, 225-245. [CrossRef]

3. Kurukulasuriya, P.; Shane, R. Climate Change and Agriculture: A Review of Impacts and Adaptations; Environment department papers; World Bank: Washington, DC, USA, 2013. Available online: https://openknowledge.worldbank.org/handle/10986/16616 (accessed on 8 March 2019).

4. Mukherjee, S.; Mishra, A.; Trenberth, K.E. Climate change and drought: A perspective on drought indices. Curr. Clim. Chang. Rep. 2018, 4, 145-163. [CrossRef]

5. Emadodin, I.; Reinsch, T.; Taube, F. Drought and desertification in Iran. Hydrology 2019, 6, 66. [CrossRef]

6. Tigkas, D.; Vangelis, H.; Tsakiris, G. Drought characterisation based on an agriculture-oriented standardised precipitation index. Theor. Appl. Climatol. 2019, 135, 1435-1447. [CrossRef]

7. Raval, A.; Ramanathan, V. Observational determination of the greenhouse effect. Nature 1989, 342, 758-761. [CrossRef]

8. Kalnay, E.; Cai, M. Impact of urbanization and land-use change on climate. Nature 2003, 423, 528-531. [CrossRef]

9. Emadodin, I.; Bork, H.R. Degradation of soils as a result of long-term human-induced transformation of the environment in Iran: An overview. J. Land Use Sci. 2012, 7, 203-219. [CrossRef]

10. Dirmeyer, P.A.; Niyogi, D.; de Noblet-Ducoudré, N.; Dickinson, R.E.; Snyder, P.K. Impacts of land-use change on climate. Int. J. Climatol. 2010, 30, 1905-1907. [CrossRef]

11. Emadodin, I.; Taravat, A.; Rajaei, M. Effects of urban sprawl on local climate: A case study, north central Iran. J. Urban Clim. 2016, 17, 230-247. [CrossRef]

12. Emadodin, I.; Reinsch, T. Assessing the impact of land use change on aridification in semi-arid land. Land Degrad. Dev. 2018, 29, 3423-3431. [CrossRef]

13. Nalbantis, I.; Tsakiris, G. Assessment of hydrological drought revisited. Water Resour. Manag. 2009, 23, 881-897. [CrossRef]

14. Tsakiris, G. Meteorological Drought Assessment; US Department of Commerce, Weather Bureau: Silver Spring, MD, USA, 2004; pp. 821-833.

15. ECA's, Background Paper: Desertification in the EU. European Court of Auditors. 2018. Available online: https://www.eca. europa.eu/Lists/ECADocuments/SR18_33/SR_DESERTIFICATION_EN.pdf (accessed on 10 October 2019).

16. Thurow, T.L.; Taylor, C.A., Jr. The role of drought in range management. J. Range Manag. 1999, 52, 413-419. [CrossRef]

17. Quiring, S.M.; Ganesh, S. Evaluating the utility of the Vegetation Condition Index (VCI) for monitoring meteorological drought in Texas. Agric. For. Meteorol. 2010, 150, 330-339. [CrossRef]

18. Quiring, S.M.; Papakryiakou, T.N. An evaluation of agricultural drought indices for the Canadian prairies. Agric. For. Meteorol. 2003, 118, 49-62. [CrossRef]

19. Kim, T.-W.; Valdes, J.B.; Aparicio, J. Frequency and spatial characteristics of droughts in the Conchos river basin, Mexico. IWRA Water Int. 2002, 27, 420-430. [CrossRef]

20. Vicario, V.; Díaz, E.; García, C.M.; Rodríguez, A. Identification of pluriannual periodicities in series of drought indexes and its relationship with macroclimatic indicators. Environ. Sustain. Indic. 2019. [CrossRef]

21. Buras, A.; Rammig, A.; Zang, S.C. Quantifying impacts of the 2018 drought on European ecosystems in comparison to 2003. Biogeosciences 2020, 17, 1655-1672. [CrossRef]

22. Tsakiris, G.; Pangalou, D. Drought Characterisation in the Mediterranean. In Coping with Drought Risk in Agriculture and Water Supply Systems. Advances in Natural and Technological Hazards Research; Iglesias, A., Cancelliere, A., Wilhite, D.A., Garrote, L., Cubillo, F., Eds.; Springer: Berlin/Heidelberg, Germany, 2009. [CrossRef]

23. Palmer, W.C. Meteorological Drought; Weather Bureau Paper No. 45 Research; US Department of Commerce, Weather Bureau: Washington, DC, USA, 1965.

24. IPCC. Climate Change 2001, the Scientific Basis. In Contribution of Working Group 1 to the Third Assessment Report of the Intergovernmental Panel on Climate Change; Cambridge University Press: Cambridge, UK, 2001.

25. EEA (European Environment Agency). Global and European Temperatures by the End of the Century. 2020. Available online: https:/ / www.eea.europa.eu/data-and-maps/indicators/global-and-european-temperature-9/assessment (accessed on 30 September 2020).

26. Gobin, A.; Jones, R.; Kirkby, M.; Campling, P.; Govers, G.; Kosmas, C.; Gentile, A.R. Indicators for pan-European assessment and monitoring of soil erosion by water. Environ. Sci. Policy 2004, 7, 25-38. [CrossRef]

27. Lei, T.; Pang, Z.; Wang, X.; Li, L.; Fu, J.; Kan, G.; Zhang, X.; Ding, L.; Li, J.; Huang, S.; et al. Drought and Carbon Cycling of Grassland Ecosystems under Global Change: A Review. Water 2016, 8, 460. [CrossRef]

28. Lei, T.; Feng, J.; Zheng, C. Review of drought impacts on carbon cycling in grassland ecosystems. Front. Earth Sci. 2020. [CrossRef] 
29. Craine, J.M.; Ocheltree, T.W.; Nippert, J.B.; Towne, E.G.; Skibbe, A.M.; Kembel, S.W.; Fargione, J.E. Global diversity of drought tolerance and grassland climate-change resilience. Nat. Clim. Chang. 2013, 3, 63-67. [CrossRef]

30. Smit, H.; Metzger, M.; Ewert, F. Spatial distribution of grassland productivity and land use in Europe. Agric. Syst. 2008, 98, 208-219. [CrossRef]

31. Pecl, G.T.; Araújo, M.B.; Bell, J.D.; Blanchard, J.; Bonebrake, T.C. Biodiversity redistribution under climate change: Impacts on ecosystems and human well-being. Science 2017, 355, 987-997. [CrossRef]

32. Ciais, P.; Reichstein, M.; Viovy, N.; Granier, A.; Ogée, J.; Allard, V. Europe-wide reduction in primary productivity caused by the heat and drought in 2003. Nature 2005, 437, 529-532. [CrossRef]

33. EU (European Commission). JRC MARS Bulletin Update on Pasture Condition. 2019. Available online: https://ec.europa.eu/jrc/ en/science-update/jrc-mars-bulletin-update-pasture-conditions (accessed on 11 August 2019).

34. Soussana, J.F.; Tallec, T.; Blanfort, V. Mitigating the greenhouse gas balance of ruminant production systems through carbon sequestration in grasslands. Animal 2010, 4, 334-350. [CrossRef] [PubMed]

35. Shepherd, M.; Lucci, G.; Vogeler, I.; Balvert, S. The effect of drought and nitrogen fertiliser addition on nitrate leaching risk from a pasture soil; an assessment from a field experiment and modelling. J. Sci. Food Agric. 2018, 98, 3795-3805. [CrossRef]

36. Reinsch, T.; Malisch, C.; Loges, R.; Taube, F. Nitrous oxide emissions from grass-clover swards as influenced by sward age and biological nitrogen fixation. Grass Forage Sci. 2020, 75, 372-384. [CrossRef]

37. Reinsch, T.; Loges, R.; Kluß, C.; Taube, F. Renovation and conversion of permanent grass-clover swards to pasture or crops: Effects on annual N2O emissions in the year after ploughing. Soil Tillage Res. 2018, 175, 119-129. [CrossRef]

38. Zhang, Y.; Cai, W.; Chen, Q.; Yao, Y.; Liu, K. Analysis of Changes in Precipitation and Drought in Aksu River Basin, Northwest China. Adv. Meteorol. 2015, 4, 1-15. [CrossRef]

39. Heim, R.R. A review of twentieth-century drought indices used in the United States. Bull. Am. Meteorol. Soc. 2002, 83, 1149-1165. [CrossRef]

40. Mishra, A.K.; Singh, V.P. A review of drought concepts. J. Hydrol. 2010, 391, 202-216. [CrossRef]

41. Mustafa, A.; Rahman, G. Assessing the spatio-temporal variability of meteorological drought in Jordan. Earth Syst. Environ. 2018, 2, 247-264. [CrossRef]

42. Ghadami, M.; Raziei, T.; Amini, M.; Modarres, R. Regionalization of drought severity-duration index across Iran. Nat Hazards. 2020. [CrossRef]

43. Paulo, A.A.; Pereira, L.S. Stochastic prediction of drought class transitions. Water Resour. Manag. 2008, 22, 1277-1296. [CrossRef]

44. Tabari, H.; Abghari, H.; Hosseinzadeh Talaee, P. Temporal trends and spatial characteristics of drought and rainfall in arid and semiarid regions of Iran. Hydrol. Process. 2012, 26, 3351-3361. [CrossRef]

45. Tsakiris, G.; Pangalou, D.; Vangelis, H. Regional drought assessment based on the Reconnaissance Drought Index (RDI). Water Resour. Manag. 2007, 21, 821-833. [CrossRef]

46. McKee, T.B.; Doesken, N.J.; Kleist, J. The relationship of drought frequency and duration to time scales. In Proceedings of the 8th Conference on Applied Climatology, Anaheim, CA, USA, 17-22 January 1993; pp. 179-184.

47. WMO, World Meteorological Organization. Standardized Precipitation Index; World Meteorological Organization: Geneva, Switzerland, 2012.

48. Tallaksen, L.M. Streamflow drought frequency analysis. In Drought and Drought Mitigation in Europe; Springer: Berlin/Heidelberg, Germany, 2000; pp. 103-117.

49. Espinosa, L.A.; Portela, M.M.; Filho, J.D.P.; Carballo Studart, T.M.; Santos, J.F.; Rodrigues, R. Jointly modeling drought characteristics with smoothed regionalized SPI series for a small island. Water 2019, 11, 2489. [CrossRef]

50. Lloyd-Hughes, B.; Saunders, M. A drought climatology for Europe. Int. J. Climatol. 2002, 22, 1571-1592. [CrossRef]

51. Box-Steffensmeier, J.M.; Bradford, S.J. Event History Modeling: A Guide for Social Scientists. In Analytical Methods for Social Research Series; Cambridge University Press: Cambridge, UK, 2004.

52. Dutta, D.; Kundu, A.; Patel, N.R.; Saha, S.K.; Siddiqui, A.R. Assessment of agricultural drought in Rajasthan (India) using remote sensing derived vegetation condition index (VCI) and standardized precipitation index (SPI). Egypt. J. Remote Sens. Space Sci. 2015, 18, 53-63. [CrossRef]

53. Tigkas, D. Drought characterization and monitoring in regions of Greece. Eur Water. 2008, 23-24, 29-39.

54. Deniz, A.; Toros, H.; Incecik, S. Spatial variations of climate indices in Turkey. Int. J. Climatol. 2011, 31, 394-403. [CrossRef]

55. Vicente-Serrano, S.M.; Beguería, S.; López-Moreno, J.I. A Multiscalar Drought Index Sensitive to Global Warming: The Standardized Precipitation Evapotranspiration Index. J. Clim. 2010, 23, 1696-1718. [CrossRef]

56. De Martonne, E. Aréisme et Indice Artidite; Comptes Rendus de l'Académie Des Sciences: Paris, France, $1926 ;$ pp. $1395-1398$.

57. Feng, G.; Cobb, S.; Abdo, Z.; Fisher, D.K.; Ouyang, Y.; Adeli, A.; Jenkins, J.N. Trend analysis and forecast of precipitation, reference evapotranspiration, and rainfall deficit in the Blackland Prairie of Eastern Mississippi. J. Appl. Meteor. Climatol. 2016, 55, 1425-1439. [CrossRef]

58. Reinsch, T.; Loges, R.; Kluß, C.; Taube, F. Effect of grassland ploughing and reseeding on $\mathrm{CO}_{2}$ emissions and soil carbon stocks. Agric. Ecosyst. Environ. 2018, 265, 374-383. [CrossRef]

59. Loges, R.; Bunne, I.; Reinsch, T.; Malisch, C.; Kluß, C.; Herrmann, A.; Taube, F. Forage production in rotational systems generates similar yields compared to maize monocultures but improves soil carbon stocks. Eur. J. Agron. 2018, 97, 11-19. [CrossRef]

60. Klapp, E.; Stählin, A. Standorte, Pflanzengesellschaften und Leistung des Grünlandes; Verlag Eugen Ulmer: Stuttgart, Germany, 1936. 
61. Ooi, M.K.J.; Auld, T.D.; Denham, A.J. Projected soil temperature increase and seed dormancy response along an altitudinal gradient: Implications for seed bank persistence under climate change. Plant Soil 2012, 353, 289-303. [CrossRef]

62. Adams, R.M.; Hurd, B.H.; Lenhart, S.; Leary, N. Effects of global climate change on agriculture: An interpretative review. Clim. Res. 1998, 11, 19-30. [CrossRef]

63. Foster, T.; Brozović, N.; Butler, A.P. Why well yield matters for managing agricultural drought risk. Weather Clim. Extrem. 2015, 10, 11-19. [CrossRef]

64. Mohmmed, A.; Zhang, K.; Kabenge, M.; Keesstra, S.; Cerda, A.; Reuben, M.; Elbashier, M.M.A.; Dalson, T.; Ali, A.A.S. Analysis of drought and vulnerability in the North Darfur region of Sudan. Land Degrad. Dev. 2018, 29, 4424-4438. [CrossRef]

65. Izaurralde, R.C.; Thomson, A.M.; Morgan, J.A.; Fay, P.A.; Polley, H.W.; Hatfield, J.L. Climate impacts on agriculture: Implications for forage and rangeland production. Agron. J. 2011, 103, 370-381. [CrossRef]

66. Bollig, C.; Feller, U. Impacts of drought stress on water relations and carbon assimilation in grassland species at different altitudes. Agric. Ecosyst. Environ. 2014, 188, 212-220. [CrossRef]

67. Durand, J.L.; Gonzalez-Dugo, V.; Gastal, F. How much do water deficits alter the nitrogen nutrition status of forage crops? Nutr. Cycl. Agroecosyst. 2010, 88, 231-243. [CrossRef]

68. NDMC (National Drought Mitigation Center). Types of Droughts. University of Nebraska-Lincoln. Available online: https: / / drought.unl.edu/Education/DroughtIn-depth/TypesofDrought.aspx (accessed on 15 September 2020).

69. EDO (European Drought Observatory). Standardized Precipitation Index (SPI). 2020. Available online: https:/ / edo.jrc.ec.europa. eu/documents/factsheets/factsheet_spi.pdf (accessed on 9 May 2020). 